Volume 1, Nomor 2, September 2019, pp 48-63. Copyright (C 2019 JAFTA, Program Studi Magister Akuntansi, Fakultas Ekonomi, Universitas Kristen Maranatha. ISSN: 2654-4636| E-ISSN: 2656-758X https://journal.maranatha.edu/index.php/jafta

\title{
Pengaruh Struktur Aktiva, Profitabilitas Dan Ukuran Perusahaan Terhadap Struktur Modal Pada Perusahaan Makanan Dan Minuman Yang Terdaftar Di Bursa Efek Indonesia Tahun 2015-2017
}

\author{
Oleh: \\ Siti Ruhana Dara \\ Basuki Toto Rahmanto \\ Institut Teknologi dan Bisnis Kalbis, Jl. Pulomas Selatan Kav.22 Jakarta Timur \\ email: sitidara@kalbis.ac.id
}

\begin{abstract}
ABSTRAK
Penelitian ini bertujuan untuk menganalisis pengaruh dari struktur aktiva, profitabilitas dan ukuran perusahaan terhadap Struktur Modal. Dalam penelitian ini, struktur modal diukur dengan menggunakan debt to equity ratio, untuk struktur aktiva dihitung dengan skala rasio, perbandingan Antara aktiva tetap dengan total aktiva, sedangkan untuk profitabilitas dengan menghitung Return on Assets dan ukuran perusahaan di hitung dengan nilai logaritma natural dari penjualan, objek dalam penelitian ini adalah perusahaan makanan dan minuman yang terdaftar di Bursa Efek Indonesia dari tahun 2015-2017. Metode pengambilan sampel, non probability sampling dengan kriteria perusahaan makanan dan minuman yang sudah dan masih terdaftar di Bursa Efek Indonesia tahun 2015-2017 yang memiliki laporan keuangan lengkap sesuai dengan variabel yang dibutuhkan. Jenis penelitian ini adalah penelitian kuantitatif dengan menggunakan analisis regresi linier berganda dan menggunakan software eviews 9 untung pengolahan datanya. Hasil penelitian menunjukkan bahwa struktur aktiva berpengaruh terhadap struktur modal sedangkan profitabilitas dan ukuran perusahaan tidak berpengaruh terhadap struktur modal.
\end{abstract}

Kata kunci: Struktur Aktiva, Profitabilitas, Ukuran Perusahaan, Struktur Modal

\section{ABSTRACT}

This study aims to analyze the effect of the structure of assets, profitability and size of the company on the Capital Structure. In this study, capital structure is measured by using a debt to equity ratio, for asset structure calculated by a ratio scale, the ratio between fixed assets and total assets, while for profitability by calculating Return on Assets and company size calculated by the natural logarithm of sales, The object of this research is food and beverage companies listed on the Indonesia Stock Exchange from 2015-2017. The sampling method is non probability sampling with the criteria of food and beverage companies that have been and are still listed on the Indonesia Stock Exchange in 2015-2017 which have complete financial statements in accordance with the variables needed. This type of research is quantitative research using multiple linear regression analysis and using software eviews 9 profit processing data. The results of the study show that the structure of assets affects the capital structure while the profitability and size of the company does not affect the capital structure.

Keywords: Asset Structure, Profitability, Company Size, Capital Structure

\section{Pendahuluan}

\subsection{Latar Belakang}

Aktivitas perekonomian di Indonesia sangat didukung oleh pertumbuhan sektor-sektor industri. Salah satu sektor industri yang diharapkan terus akan bertahan adalah sektor industri makanan dan minuman, karena merupakan salah satu industri yang dapat memenuhi kebutuhan masyarakat. Industri makanan dan minuman adalah industri yang paling lama tahan terhadap krisis, karena industri ini memenuhi kebutuhan pokok masyarakat, yang kita ketahui bahwa jumlah masyarakat Indonesia kurang lebih sebanyak 250 juta jiwa, kebutuhan makanan dan minuman adalah kebutuhan yang harus dipenuhi setiap harinya, maka potensi bertumbuh untuk sektor 
industri ini adalah sangat besar. Dalam industri dengan pertumbuhan yang tinggi, tentunya banyak pesaing dalam industri tersebut. Dalam hal ini maka perusahaan harus dapat tetap mempertahankan kualitasnya dan memiliki diferensiasi serta keunggulan untuk dapat tetap mempertahankan bahkan menambah pangsa pasarnya. Perusahaan dituntut harus memiliki dana yang mencukupi untuk dapat terus mengembangkan kualitas produknya. Manajer keuangan harus dapat mengambil keputusan yang baik dan tepat dalam penggunaan dana secara maksimal.

Apabila suatu perusahaan dalam memenuhi kebutuhan dananya mengutamakan pemenuhan dengan sumber dari dalam perusahaan akan sangat mengurangi ketergantungan kepada pihak luar. Apabila kebutuhan dana sudah demikian meningkatnya karena pertumbuhan perusahaan, dan dana dari sumber intern sudah digunakan semua, maka tidak ada pilihan lain selain mengguanakan dana yang berasal dari luar perusahaan, baik dari utang (debt financing) maupun dengan mengeluarkan saham baru (external equity financing) dalam memenuhi kebutuhan akan dananya. Struktur modal adalah perimbangan atau perbandingan antara modal asing (jangka panjang) dengan modal sendiri. Baik dan buruk struktur modal akan mempunyai efek yang langsung terhadap posisi finansial perusahaan. Struktur modal itu sendiri dipengaruhi oleh banyak faktor dimana faktor-faktor yang utama adalah tingkat bunga, stabilitas dari "earning”, susunan dari aktiva, kadar risiko dari aktiva, besarnya jumlah modal yang dibutuhkan, keadaan pasar modal, sifat manajemen, besarnya suatu perusahaan (Riyanto,2001:296).

Dalam penelitian yang dilakukan oleh Hadianto (2010) yang meneliti tentang struktur modal menghasilkan temuan bahwa struktur aktiva berpengaruh positif secara signifikan terhadap struktur modal, Ukuran perusahaan berpengaruh negatif secara signifikan terhadap struktur modal, profitabilitas berpengaruh positif secara signifikan terhadap struktur modal. Struktur aktiva dapat menggambarkan sebagian jumlah aset perusahaan yang dapat dijadikan jaminan. Dalam memperoleh pendanaan eksternal jaminan merupakan hal utama yang dapat dijadikan acuan untuk mendapatkan pinjaman. Logikanya, perusahaan dengan profitabilitas yang tinggi lebih akan meminimumkan penggunaan pinjaman dana dari eksternal dan akan memanfaatkan dana internal, sehingga dalam hal ini struktur modal lebih kecil karena, Perusahaan akan memanfaatkan laba ditahan sebagai sumber tercepat untuk penambahan modal perusahaannya. Dalam penelitian ini peneliti akan menggunakan pengukuran Return On Asset (ROA) sebagai pengukuran untuk profitabilitas. Riyanto (2001:305) berpendapat bahwa ukuran perusahaan menggambarkan besar kecilnya suatu perusahaan yang ditunjukkan pada total aktiva, jumlah penjualan, rata-rata penjualan. Semakin besar ukuran suatu perusahaan, maka kecenderungan menggunakan modal asing juga akan semakin besar.

Berdasarkan latar belakang tersebut, serta hasil penelitian terdahulu maka dalam penelitian ini akan di uji beberapa faktor yang mempengaruhi struktur modal untuk perusahaan makanan dan minuman yang terdaftar di Bursa Efek Indonesia tahun 2015-2017.

\subsection{Perumusan Masalah}

Rumusan masalah dari penelitian ini dibagi menjadi 3 rumusan masalah. Adapun rumusan masalah dalam penelitian ini antara lain:

1. Apakah faktor Struktur Aktiva berpengaruh terhadap struktur modal pada perusahaan makanan dan minuman yang terdaftar di Bursa Efek Indonesia?

2. Apakah faktor Profitabilitas berpengaruh terhadap struktur modal pada perusahaan makanan dan minuman yang terdaftar di Bursa Efek Indonesia? 
JAFTA — Vol. 1 Nomor 2, September (2019)

3. Apakah faktor Ukuran Perusahaan berpengaruh terhadap struktur modal pada perusahaan makanan dan minuman yang terdaftar di Bursa Efek Indonesia?

\subsection{Tujuan Penelitian}

Sesuai dengan rumusan masalah diatas, maka tujuan penelitian ini adalah:

1. Untuk menganalisis pengaruh faktor Struktur Aktiva terhadap struktur modal pada perusahaan makanan dan minuman yang terdaftar di Bursa Efek Indonesia.

2. Untuk menganalisis pengaruh faktor Profitabilitas terhadap struktur modal pada perusahaan makanan dan minuman yang terdaftar di Bursa Efek Indonesia.

3. Untuk menganalisis pengaruh faktor Ukuran Perusahaan berpengaruh signifikan positif terhadap struktur modal pada perusahaan makanan dan minuman yang terdaftar di Bursa Efek Indonesia.

\section{RERANGKA TEORIS}

\subsection{Teori-teori Berkaitan Dengan Masalah} Pokok Penelitian

\subsubsection{Struktur Modal}

Struktur modal adalah perimbangan atau perbandingan antara modal asing (jangka panjang) dengan modal sendiri (Riyanto, 2001:296). Struktur modal memiliki pengertian yang lebih sempit dari struktur keuangan. Struktur modal menunjukkan komposisi penggunaan dana jangka panajng. Sementara struktur keuangan menunjukkan komposisi seluruh dana, baik jangka pendek.

\subsubsection{Faktor-Faktor yang Mempengaruhi Struktur Modal}

Riyanto (2001:296) Masalah struktur modal merupakan masalah yang penting bagi setiap perusahaan. Karena baik buruknya struktur modalnya akan mempunyai efek yang langsung terhadap posisi finansial perusahaan. Suatu perusahaan yang mempunyai struktur modal yang tidak baik, di mana mempunyai utang yang sangat besar akan memberikan beban yang berat kepada perusahaan yang bersangkutan. Struktur modal merupakan cermin dari kebijakan perusahaan dalam menentukan "jenis" securities yang dikeluarkan. Struktur modal suatu perusahaan dipengaruhi oleh banyak faktor di mana faktor-faktor yang utama ialah:

1. Tingkat Bunga

Pada waktu perusahaan merencanakan pemenuhan kebutuhan modal adalah sangat dipengaruhi oleh tingkat bunga yang berlaku pada waktu itu. Tingkat bunga akan mempengaruhi pemilihan jenis modal apa yang akan ditarik, apakah perusahaan akan mengeluarkan saham atau obligasi. Penarikan obligasi hanya dibenarkan apabila tingkat bunganya lebih rendah daripada "earning power" dari tambahan modal tersebut.

2. Stabilitas dari "Earning"

Stabilitas dan besarnya "earning" yang diperoleh oleh suatu perusahaan akan menentukan apakah perusahaan tersebut dibenarkan untuk menarik modal dengan beban tetap atau tidak. Suatu perusahaan yang mempunyai "earning" yang stabil akan selalu dapat memenuhi kewajiban finansiilnya sebagai akibat dari penggunaan modal asing. Sebaliknya perusahaan yang mempunyai "earning" tidak stabil dan "unpredictable" akan menanggung risiko tidak dapat membayar beban bunga atau tidak dapat membayar angsuran-angsuran utangnya pada tahun-tahun atau keadaan yang buruk 
JAFTA — Vol. 1 Nomor 2, September (2019)

3. Susunan dari Aktiva

Kebanyakan perusahaan industri di mana sebagian besar dari modalnya tertanam dalam aktiva tetap (fixed assets), akan mengutamakan pemenuhan kebutuhan modalnya dari modal yang permanen, yaitu modal sendiri, sedangkan modal asing sifatnya adalah sebagi pelengkap. Hal ini dapat dihubungkan dengan adanya aturan struktur finansil konservatif yang horizontal yang menyatakan bahwa besarnya modal sendiri hendaknya paling sedikit dapat menutup jumlah aktiva tetap plus aktiva lain yang sifatnya permanen. Dan perusahaan yang sebagian besar dari aktivanya sendiri dari aktiva lancer akan mengutamakan pemenuhan kebutuhan dananya dengan utang jangka pendek.

4. Kadar risiko dari aktiva

Tingkat atau kadar risiko dari setiap aktiva di dalam perusahaan adalah tidak sama. Makin panjang jangka waktu penggunaan suatu aktiva di dalam perusahaan, makin besar derajat risikonya. Dengan perkembangan kemajuan teknologi dan ilmu pengetahuan yang tidak ada henti-hentinya, dalam artian ekonomis dapat mempercepat tidak digunakannya suatu aktiva, meskipun dalam artian teknis masih dapat digunakan.

5. Besarnya jumlah modal yang dibutuhkan Apabila jumlah modal yang dibutuhkan sekiranya dapat dipenuhi hanya dari satu sumber saja, maka tidaklah perlu mencari sumber lain. Sebaliknya apabila jumlah modal yang dibutuhkan adalah sangat besar, sehingga tidak dapat dipenuhi dari satu sumber saja (misalnya dengan saham biasa), maka perlulah dicari sumber yang lain (misalnya dengan saham preferen dan obligasi).
6. Keadaan pasar modal

Keadaan pasar modal sering mengalami perubahan disebabkan karena adanya gelombang konjungtur. Pada umumnya apabila gelombang meninggi (up-swing) para investor lebih tertarik untuk menanamkan modalnya dalam saham. Berhubungan dengan itu maka perusahaan dalam rangka usaha untuk mengeluarkan atau menjual securities haruslah menyesuaikan dengan keadaan pasar modal tersebut.

7. Sifat manajemen

Sifat manajemen akan mempunyai pengaruh yang langsung dalam pengambilan keputusan mengenai cara pemenuhan kebutuhan dana.seorang manajer yang bersifat optimis yang memandang masa depannya dengan cerah, yang mempunyai keberanian untuk menanggung risiko yang besar (risk seeker), akan lebih berani untuk membiayai pertumbuhan penjualannya dengan dana yang berasal dari utang (debt financing) meskipun metode pembelanjaan dengan utang ini memberikan beban finansiil yang tetap. Sebaliknya seorang manajer yang bersifat pesimis, yang serba takut untuk menanggung risiko (risk averter) akan lebih suka membelanjai pertumbuhan penjualannya dengan dana yang berasal dari sumber intern atau dengan modal saham (equity financing) yang tidak mempunyai beban financial yang tetap.

8. Besarnya suatu perusahaan

Suatu perusahaan yang besar di mana sahamnya tersebar sangat luas, setiap perluasan modal saham hanya akan mempunyai pengaruh yang kecil terhadap kemungkinan hilangnya atau tergesernya control dari pihak dominan terhadap perusahaan yang bersangkutan. Sebaliknya 
JAFTA — Vol. 1 Nomor 2, September (2019)

perusahaan yang kecil di mana sahamnya hanya tersebat di lingkungan kecil, penambahan jumlah saham akan mempunyai pengaruh yang besar terhadap kemungkinan hilangnya kontrol pihak dominan terhadap perusahaan yang bersangkutan. Dengan demikian maka pada perusahaan yang besar di mana sahamnya tersebar sangat luas akan lebih berani mengeluarkan saham baru dalam memenuhi kebutuhannya untuk membiayai pertumbuhan penjualan di bandingkan dengan perusahaan yang kecil.

\subsubsection{Teori Struktur Modal}

Riyanto (2001:298), Teori struktur modal pada hakikatnya berusaha menjawab pertanyaan, apakah perbedaan struktur modal memiliki pengaruh terhadap biaya modal perusahaan. Keputusan struktur modal relevan untuk dipertimbangkan, jika memiliki pengaruh terhadap biaya modal, dan sebalinya menjadi tidak relevan jika tidak berpengaruh apa-apa. Perumusan teori struktur modal, umumnya dimulai dengan mengasumsikan bahwa terdapat pasar modal yang sempurna. Kondisi yang melandasi terciptanya pasar modal yang sempurna adalah:

1. Tidak ada pajak

2. Perubahan komposisi utang dan ekuiti dapat dilakukan secara langsung karena tidak ada biaya transaksi.

3. Seluruh keuntungan perusahaan dibandingkan sebagi dividen

4. Semua pemodal memiliki pengharapan yang seragam terhadap distribusi keuntungan perusahaan.

5. Keuntungan operasi bersifat konstan atau tetap.

Ada dua pendekatan yang berbeda, yaitu pendekatan tradisional dan pendekatan ModiglianiMiller (MM). pendekatan tradisional menyatakan bahwa dalam kondisi pasar modal yang sempurna, keputusan struktur modal menjadi relevan. Perusahaan dapat menurunkan biaya modalnya dengan menambah jumlah utang, meskipun biaya modal sendiri akan bertambah besar. Hal ini karena biaya utang lebih rendah dari biaya modal sendiri. Tetapi seiring dengan semakin banyaknya jumlah utang (disebut sebagai tingkat leverage yang semakin tinggi), maka selain biaya modal sendiri bertambah tinggi, biaya utang juga mengalami kenaikan. Akibatnya, biaya modal perusahaan secara keseluruhan akan bertambah besar. Perusahaan harus menentukan tingkat leverage yang mampu mengoptimalkan biaya modalnya.

\subsection{Hipotesis}

\subsubsection{Struktur Aktiva}

Ketika perusahaan membutuhkan modal, tentunya perusahaan akan mengutamakan pemenuhan kebutuhan dari modal sendiri, sedangkan modal asing sifatnya adalah sebagai pelengkap, karena kebanyakan perusahaan industri sebagian besar dari modalnya tertanam dalam aktiva tetap (Riyanto, 2001:297), maka hipotesis pertama adalah:

H1: Struktur aktiva berpengaruh terhadap struktur modal

\subsubsection{Profitabilitas}

Perusahaan dengan tingkat pengembalian atas investasi yang sangat tinggi ternyata menggunakan utang dalam jumlah yang relatif sedikit, tingkat pengembalian yang tinggi memungkinkan perusahaan-perusahaan tersebut melakukan sebagian besar pendanaannya melalui dana yang dihasilkan secara internal (Brigham dan Huston, 2011:189). Berdasarkan teori tersebut, maka hipotesis kedua adalah:

H2: Profitabilitas berpengaruh terhadap struktur modal 
JAFTA — Vol. 1 Nomor 2, September (2019)

\subsubsection{Ukuran Perusahaan}

Perusahaan yang besar, yang sahamnya tersebar luas dengan perluasan modal sahamnya hanya akan mempunyai pengaruh yang kecil terhadap kemungkinan hilangnya atau tergesernya control dari pihak dominan terhadap perusahaan yang bersangkutan (Riyanto, 2001:297). Hipotesis ketiga:

H3: Ukuran perusahaan berpengaruh terhadap struktur modal

Selain ketiga hipotesis diatas, akan diuji apakah secara bersama sama struktur aktiva, profitabilitas dan ukuran perusahaan mempengaruhi struktur modal. Maka hipotesisnya adalah:
H4: struktur aktiva, profitabilitas dan ukuran perusahaan berpengaruh terhadap struktur modal.

\section{METODE PENELITIAN}

\subsection{Jenis Penelitian}

Penelitian ini merupakan penelitian dengan pendekatan kuantitatif. Menurut Sugiyono (2012:11) penelitian kuantitatif dalam melihat hubungan variabel terhadap objek yang diteliti lebih bersifat sebab dan akibat (kausal), sehingga dalam penelitiannya ada variabel independen dan dependen.

\subsection{Definisi Konseptual dan Operasional Variabel}

Tabel 3.1. Operasionalisasi Variabel

\begin{tabular}{|c|c|c|c|}
\hline Variabel & Definisi & Indikator & Satuan \\
\hline Struktur Aktiva $\left(\mathrm{X}_{1}\right)$ & $\begin{array}{l}\text { Kebanyakan perusahaan industri di mana sebagian besar dari modalnya tertanam } \\
\text { dalam aktiva tetap (fuxed assets), akan mengutamakan pemenuhan kebutuhan } \\
\text { modalnya dari modal yang permanen, yaitu modal sendiri, sedangkan modal asing } \\
\text { sifatnya adalah sebagi pelengkap. }\end{array}$ & $\begin{array}{l}\text { Total Aktiva Tetap/ Total } \\
\text { Aktiva }\end{array}$ & Rasio \\
\hline Profitabilitas $\left(\mathrm{X}_{2}\right)$ & $\begin{array}{l}\text { Rasio yang mengukur kemampuan perusahaan dalam mendapatkan keuntungan atau } \\
\text { laba. }\end{array}$ & Net profit/Total Asset & Rasio \\
\hline Ukuran Perusahaan $\left(\mathrm{X}_{3}\right)$ & $\begin{array}{l}\text { Perusahaan yang besar di mana sahamnya tersebar sangat luas akan lebih berani } \\
\text { mengeluarkan saham baru dalam memenuhi kebutuhannya untuk membiayai } \\
\text { pertumbuhan penjualan di bandingkan dengan perusahaan yang kecil. }\end{array}$ & Ln (penjualan) & Rasio \\
\hline Struktur Modal (Y) & $\begin{array}{l}\text { Perimbangan atau perbandingan antara modal asing (jangka panjang) dengan modal } \\
\text { sendiri (Riyanto, 2001:296). }\end{array}$ & $\begin{array}{l}\text { Total Hutang / Total } \\
\text { Modal }\end{array}$ & Rasio \\
\hline
\end{tabular}

Sumber: Data diolah peneliti

Dalam kerangka konsep penelitian ada 3 variabel bebas atau independen yaitu Struktur Aktiva, Profitabilitas dan Ukuran Perusahaan. Sedangkan untuk variabel independennya hanya 1 yakni
Struktur Modal. Dari konsep penelitian seperti ini, peneliti dapat menguji 3 hipotesis yang sudah dijelaskan pada bab sebelumnya.

Gambar 3.2. Kerangka konsep penelitian

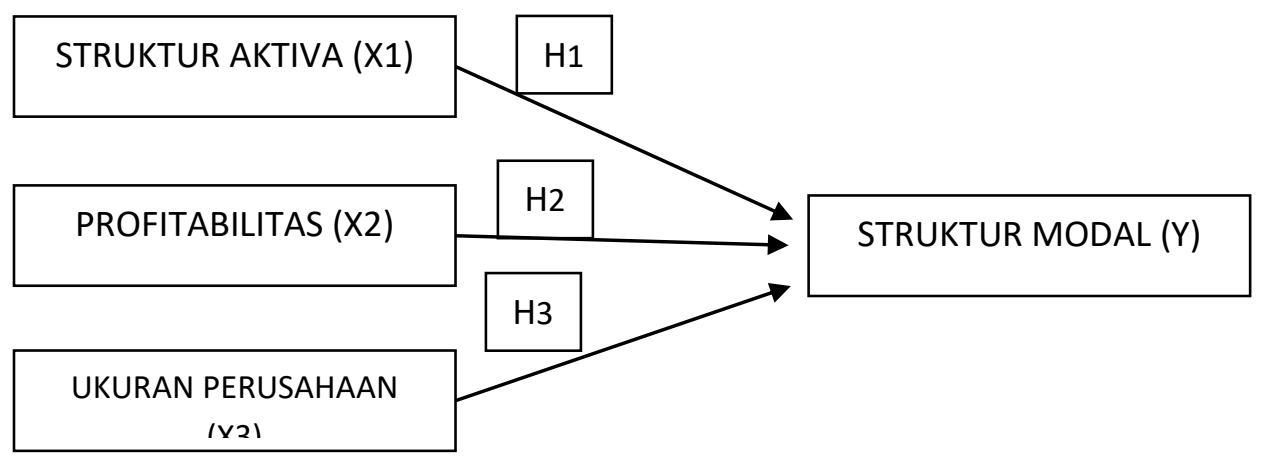




\subsection{Populasi dan Sampel}

Populasi diartikan sebagai wilayah generalisasi yang terdiri atas: objek/subjek yang mempunyai kualitas dan karakteristik tertentu yang ditetapkan oleh peneliti untuk dipelajari dan kemudian ditarik kesimpulannya. Sedangkan sampel adalah sebagian dari populasi itu (Sugiyono,2012:80). Dalam penelitian ini seluruh perusahaan yang tercatat di Bursa Efek Indonesia menjadi populasi penelitian, dan yang akan dijadikan sampel adalah perusahaan-perusahaan yang dalam industri makanan dan minuman yang terdaftar di Bursa Efek Indonesia dari tahun 20152017 yang memiliki laporan keuangan sesuai dengan variabel yang dibutuhkan dalam penelitian.

Dalam penelitian ini teknik pengambilan sampel yang digunakan adalah teknik nonprobability sampling yaitu teknik pengambilan sampel yang tidak memberi peluang/kesempatan sama bagi setiap unsur atau anggota populasi untuk dipilih menjadi sampel Sugiyono (2012:218). Ini berarti tidak semua elemen dalam populasi memiliki kesempatan yang sama untuk dipilih menjadi sampel.

Metode pengambilan sampel menggunakan metode purposive sampling, yaitu dipilih dengan pertimbangan dan tujuan tertentu. Kriteria sampel dalam penelitian ini adalah:

1. Sampel merupakan perusahaanperusahaam dalam industri makanan yang sudah dan masih terdaftar di Bursa Efek Indonesia dari tahun 2015-2017.

2. Perusahaan yang memiliki data keuangan lengkap untuk menghitung variabelvariabel dalam penelitian ini selama periode pengamatan yaitu tahun 20152017.

\subsection{Metode Pengumpulan Data}

Dalam penelitian ini data dari sampel penelitian didapat dari website resmi Bursa Efek Indonesia (www.idx.co.id), dengan mengambil data laporan keuangan publikasi untuk perusahaan dalam industri makanan dan minuman yang terdaftar dan tersedia laporan keuangannya dari tahun 2015-2017.

Berdasarkan kriteria diatas maka terpilihlah 13 sampel penelitian, 5 perusahaan tidak masuk dalam sampel karena laporan keuangan tidak memenuhi kriteria penelitian.

\subsection{Metode Analisis Data}

Penelitian ini untuk mengetahui bagaimana pengaruh antara struktur aktiva, profitabilitas dan ukuran perusahaan terhadap struktur modal pada perusahaan dalam industri makanan dan minuman yang terdaftar di Bursa Efek Indonesia pada tahun 2015-2017. Penelitian ini menggunakan metode analisis regresi linear berganda dengan menggunakan program komputer (software) Eviews 9 dan Microsoft Office.

\subsubsection{Uji Asumsi Klasik}

\subsubsection{Uji Normalitas}

Winarno (2015:5.41) salah satu asumsi dalam analisis statistika adalah data berdistribusi normal. Dalam eviews, Jarque-bera adalah uji statistik untuk mengetahui apakah data berdistribusi normal.

- Bila nila J-B tidak signifikan (lebih kecil dari 2), maka data berdistribusi normal

- Bila probabilitas lebih besar dan 5\% (bila anda menggunakan tingkat signifikansi tersebut), maka data berdistribusi normal (hipotesis nolnya adalah data berdistribusi normal). 


\subsubsection{Uji Multikolinearitas}

Multikolinieritas adalah kondisi adanya hubungan linier antarvariabel independen (Winarno,2015:5.1). Priyatno

Multikolinearitas adalah keadaan dimana antara dua variabel independen atau lebih pada model regresi terjadi hubungan linier yang sempurna atau mendekati sempurna. Model regresi yang baik mensyaratkan tidak adanya masalah multikolinearitas. Untuk mendeteksi ada tidaknya multikolinearitas dengan melihat nilai tolerance dan VIF. Semakin kecil nilai Tolerance dan semakin besar VIF maka semakin mendekati terjadinya masalah multikolinearitas. Dalam kebanyakan penelitian menyebutkan bahwa jika tolerance lebih dari 0,1 dan VIF kurang dari 10 maka tidak terjadi multikolinearitas.

\subsubsection{Uji Heteroskedastisitas}

Heteroskedastisitas adalah keadaan dimana terjadinya ketidaksamaan varian dari residual pada model regresi. Model regresi yang baik mensyaratkan tidak adanya masalah heteroskedastisitas. Heteroskedastisitas menyebabkan penaksir atau estimator menjadi tidak efisien dan nilai koefisien determinasi akan menjadi sangat tinggi (Priyatno, 2013).

\subsubsection{Uji Autokorelasi}

(Winarno,2015:5.29) autokorelasi adalah hubungan antara residual satu observasi dengan residual observasi lainnya. Dalam mengidentifikasi autokorelasi dapat diperiksa dengan menggunakan uji Durbin-Watson. Santoso (2015:194) Untuk Uji autokorelasi dapat dilihat dari nilai DurbinWatson. Menurut apabila angka D-W diantara -2 sampai dengan +2 maka tidak terjadi autokorelasi.

\subsubsection{Analisis Regresi Berganda}

Metode analisis yang digunakan dalam penelitian ini adalah analisis regresi linier berganda yang digunakan untuk mengukur hubungan antara variabel dependen dan variabel independen. Untuk menguji hipotesis di atas digunakan model sebagai berikut :

$$
Y=\beta_{0}+\beta_{1} X_{1}+\beta_{2} X_{2}+\beta_{3} X_{3+} e
$$

Keterangan:

$$
\begin{aligned}
& \mathrm{Y}=\quad \text { Struktur Modal } \\
& \beta_{0}=\quad \text { Intercept } \\
& \beta 1-\beta 3=\text { koefisien regresi dari setiap variable }
\end{aligned}
$$

\subsubsection{Uji Hipotesa}

(Priyatno,2013) Uji hipotesa dilakukan dengan: Uji t. Uji $\mathrm{t}$ adalah untuk mengetahui pengaruh variabel independen secara parsial terhadap variabel dependen, apakah pengaruhnya signifikan atau tidak.

Tahap-tahap pengujian sebagai berikut:

a. $\mathrm{H}_{0}: \mathrm{b}_{1}=0$

$\mathrm{H}_{\mathrm{a}}: \mathrm{b}_{1} \neq 0$

b. Menentukan taraf signifikansi. Taraf signifikansi menggunakan 0,05

c. Pengambilan keputusan Probabilitas $>0,05$ jadi $\mathrm{H}_{0}$ diterima Probabilitas $<0,05$ jadi $\mathrm{H}_{0}$ ditolak

\subsubsection{Analisis koefisien determinasi}

Analisis koefisien determinasi $\left(\mathrm{R}^{2}\right)$ digunakan untuk mengetahui seberapa besar prosentase sumbengan pengaruh variabel 


\section{HASIL PENELITIAN DAN PEMBAHASAN}

\subsection{Uji Asumsi Klasik \\ 4.1.1 Uji Normalitas}

\section{Gambar 4.1 Hasil Uji Normalitas}

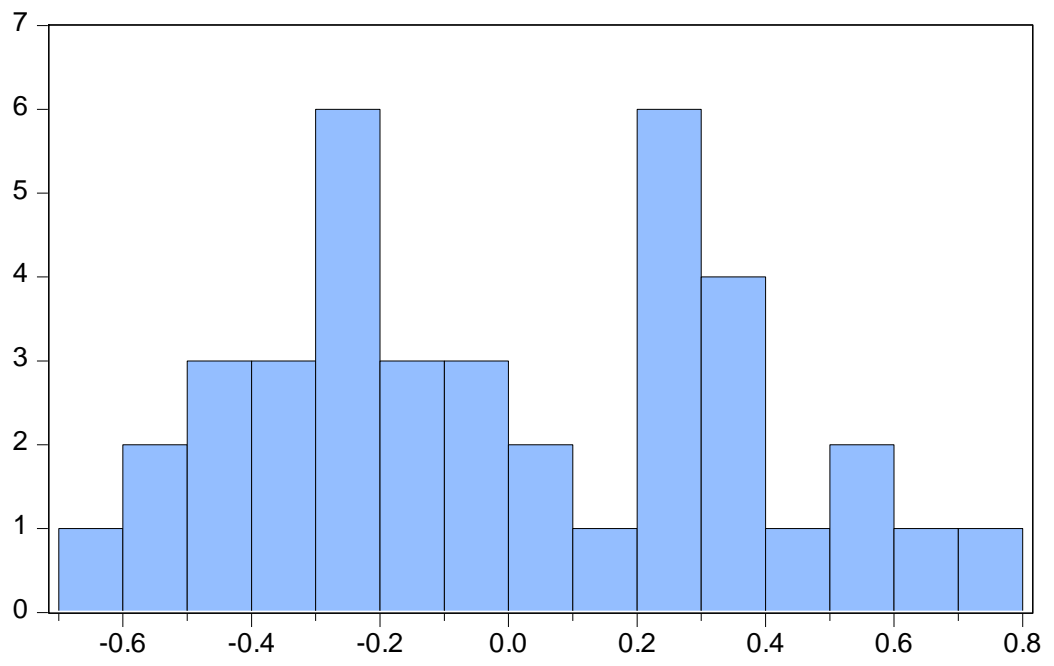

Series: Residuals

Sample 139

Observations 39

Mean

Median $\quad-0.044003$

Maximum $\quad 0.755360$

Minimum $\quad-0.626741$

Std. Dev. $\quad 0.359039$

Skewness $\quad 0.188200$

Kurtosis $\quad 2.078671$

Jarque-Bera $\quad 1.609600$

Probability $\quad 0.447177$

Sumber: Data olahan peneliti

Dari hasil uji normalitas nilai Jarque-bera (J-B) 1.609600 dan probabilitasnya 0.447177 . Nilai

J-B lebih kecil dari 2, maka data berdistribusi normal dan nilai probabilitas lebig dari nilai signifikansi 5\% maka data berdistribusi normal.

\subsubsection{Uji Multikolinearitas}

Tabel 4.1 Tabel Coefficient correlation

\begin{tabular}{cccc} 
& SA & ROA & FS \\
\hline SA & 1.000 .000 & -0.056968 & -0.296754 \\
ROA & -0.056968 & 1.000 .000 & 0.104124 \\
FS & -0.296754 & 0.104124 & 1.000 .000 \\
\hline
\end{tabular}

Sumber: Data diolah peneliti

Untuk uji multikolinearitas (Winarno 2015:5.1)

Multikolinearitas adalah kondisi adanya hubungan linier antarvariabel independen. Dari hasil analisis menunjukkan nilai coefficient correlation berada di bawah 0.8 , yang berarti tidak adanya multikolinearitas dalam penelitian ini.

\subsubsection{Uji Autokorelasi}

Untuk autokorelasi ini dapat dilihat dengan nilai Durbin-Watson. Menurut Santoso (2015:194) apabila angka D-W diantara -2 sampai dengan +2 maka tidak terjadi autokorelasi. Nilai durbin Watson yang ditunjukkan dalam tabel 4.3 adalah 0.950455 , berarti tidak adanya autokorelasi 
JAFTA — Vol. 1 Nomor 2, September (2019)

dalam model penelitian yang digunakan.

4.1.4 Uji Heteroskedastisitas

Tabel 4.2 Heteroskedasticity Test: Breusch Pagan Godfrey

\section{F-statistic $\quad 0.524715 \quad$ Prob. F(3,35) 0.6682 Obs ${ }^{*} \mathrm{R}$ - squared \\ 1.678.555 Prob. Chi-Square(3) \\ Scaled explained SS

Sumber: Data diolah peneliti

Dari hasil uji heteroskedasticity dengan lebih besar dari Alpha (0.05) atau 5\%. menggunakan tes Breusch Pagan Godfrey terbukti tidak ada masalah heteroskedastisitas 4.2 Uji Hipotesis dan pembahasan karena nilai probabilitas menunjukkan hasil 0.6417,

Tabel 4.3 Hasil Regresi

\begin{tabular}{crrrl} 
Variable & Coefficient & Std. Error & t-Statistic & Prob. \\
\hline C & -0.013836 & 0.690615 & -0.020034 & 0.9841 \\
SA & 1.809 .098 & 0.383283 & 4.720 .002 & 0.0000 \\
ROA & 0.000209 & 0.006446 & 0.032475 & 0.9743 \\
FS & 0.020293 & 0.042314 & 0.479576 & 0.6345
\end{tabular}

\begin{tabular}{lccc} 
R-squared & 0.398715 & Mean dependent var & 0.958205 \\
$\begin{array}{l}\text { Adjusted } \\
\begin{array}{l}\text { R-squared } \\
\text { S.E. of }\end{array}\end{array}$ & 0.347176 & S.D. dependent var & 0.463021 \\
$\begin{array}{l}\text { regressio } \\
n\end{array}$ & 0.374110 & Akaike info criterion & 0.968380 \\
$\begin{array}{l}\text { Sum } \\
\text { squared } \\
\text { resid }\end{array}$ & 4.898 .534 & $\begin{array}{l}\text { Schwarz criterion } \\
\text { Log }\end{array}$ & 1.139 .001 \\
$\begin{array}{l}\text { likelihood } \\
\text { F-statistic }\end{array}$ & -1.488 .340 & criter. & 1.029 .597 \\
$\begin{array}{l}\text { Prob(F- } \\
\text { statistic) }\end{array}$ & 0.000431 & Durbin-Watson stat & 0.950455 \\
\hline & & & \\
\hline
\end{tabular}

Sumber: Data diolah peneliti 
JAFTA — Vol. 1 Nomor 2, September (2019)

Berdasarkan hasil analisis regresi linier berganda pada tabel 4.3, maka dapat dibuat persamaan regresi sebagai berikut:

DER $=-\mathbf{0 . 0 1 3 8 3 6}+\mathbf{1 . 8 0 9 0 9 8 S A}+\mathbf{0 . 0 0 0 2 0 9 R O A}$ $+0.020293 F S$

\subsubsection{Pengaruh Struktur aktiva terhadap struktur modal}

Pengaruh variable Struktur Aktiva terhadap Struktur Modal (SM) Dilihat dari nilai probabilitas pada tabel 4.3 bahwa Nilai probabilitas yang ditunjukkan adalah sebesar 0.0000. nilainya lebih kecil dari nilai taraf uji 5\%. Maka variabel struktur aktiva berpengaruh terhadap variable struktur modal. Hasil ini sejalan dengan penelitian yang dilakukan sebelumnya oleh Handianto (2010) dan Aurangzeb (2012), Anila (2013) tetapi bertolak belakang dengan hasil Lutfiana dan yahya (2016) yang menunjukkan struktur aktiva tidak berpengaruh terhadap struktur modal.

\subsubsection{Pengaruh Profitabilitas terhadap struktur modal}

Pengaruh variable Profitabilitas (ROA) terhadap Struktur Modal (SM) Berdasarkan Tabel 4.3 Hasil probabilitas variable ROA nilainya 0.9743, lebih besar dari taraf uji 5\%. Berarti variable ROA tidak berpengaruh terhadap struktur modal (DER). Hasil ini bertolak belakang dengan hasil penelitian terdahulu yang menyatakan bahwa terdapat pengaruh antara rasio profitabilitas dengan struktur modal. Perbedaan hasil ini mungkin disebabkan karena perbedaan objek penelitian dan tahun pengamatan penelitian.

\subsubsection{Pengaruh Ukuran Perusahaan terhadap struktur modal}

Pengaruh variable ukuran perusahaan (FS) terhadap Struktur Modal (SM) Berdasarkan tabel 4.3 diketahui bahwa hasil perolehan nilai 58 probabilitas sebesar 0.6345 , lebih besar dari 0.05 berarti FS tidak berpengaruh terhadap Struktur Modal (SM) yang diproksikan dengan rasio DER. Hasil ini juga tidak sejalan dengan penelitian penelitian terdahulu, yang mendapatkan hasil bahwa terdapat pengaruh antara ukuran perusahaan dengan struktur modal. hal ini mungkin disebabkan karena kurang banyak sampel pengamatan penelitian.

\subsection{Koefisien Determinasi}

Uji koefisien determinasi (R2) dilihat dalam tabel 4.3 dari nilai Adjusted R-square untuk mengukur seberapa jauh kemampuan model menerangkan variasi variable dependen. Nilai Adjusted R-square 0.347176, menunjukkan model ini dapat menerangkan sebesar $34,7176 \%$ variable struktur modal.

\section{SIMPULAN DAN SARAN}

\section{$5.1 \quad$ Simpulan}

Berdasarkan pembahasan yang telah diuraikan maka ditarik simpulan sebagai berikut:

1. Struktur aktiva berpengaruh terdapat struktur modal

2. Profitabilitas tidak berpengaruh terhadap struktur modal

3. Ukuran perusahaan tidak berpengaruh terhadap struktur modal

\subsection{Saran}

Peneliti merekomendasikan untuk penelitian selanjutnya menambahkan faktor-faktor lain sebagai tambahan variabel yang diteliti. Riyanto (2001:296) menjelaskan bahwa struktur modal dapat dipengaruhi oleh banyak faktor utama, diantaranya tingkat bunga, stabilitas dari "earning", susunan aktiva, kadar risiko dari aktiva, besarnya jumlah modal yang dibutuhkan, keadaan pasar modal, sifat manajemen, besarnya suatu 
JAFTA — Vol. 1 Nomor 2, September (2019)

perusahaan. Dalam penelitian ini sudah diuji 3 dari 8 faktor tersebut, maka untuk penelitian selanjutnya dapat menambahkan 5 variabel lainnya. Selain variabel penelitian, objek dan waktu pengamatan bisa di teliti lebih lama lagi.

\section{DAFTAR PUSTAKA}

Agustini,T \& Budiyanto (2015). Pengaruh Struktur Aktiva, Profitabilitas dan Ukuran perusahaan terhadap Struktur Modal. Jurnal Ilmu dan Riset Manajemen. Volume 4, Nomor 8, Agustus 2015.

Asnawi,S dan Wijaya, C. (2005). Riset Keuangan. Jakarta: Gramedia.

Aurangzeb dan Anwar U. (2012). Determinants of Capital Structure: A Case From Textile Industry of Pakistan, International Journal of Academic Research in Business and Social Sciences, Vol. 2, No. 4

Cekrezi, A. (2013). Impact of Firm Specific Factors on Capital $\quad$ Structure Decision: An Empirical Study of Albanian Firms, European Journal of Sustainable Development, Vol. 2, No. 4, 13-148

Ahmad, G.N dan R. L. (2017). Analysis of Effect of Profitability, Assets Structure, Size of Companies, and Liquidity to Capital Structure in Mining Companies Listed in Indonesia Stock Exchange Period 20122015. Jurnal Riset Manajemen Sains Indonesia (JRMSI) Vol.8, No.2, 2017.

Ghozali, I. (2016). Aplikasi Analisis Multivariate dengan program IBM SPSS 23.Badan penerbit Universitas Diponegoro.

Hadianto, B. (2010). Pengaruh Struktur Aktiva, ukuran perusahaan dan profitabilitas terhadap struktur modal emiten sektor telekomunikasi periode 2000-2006;sebuah pengujian pecking order. Jurnal Manajemen Maranatha, Vol.7.

Hartanto,A. (2017). "Sektor Industri Tumbuh Tinggi dari Ekonomi Nasional". [Online]. Diakses 25 Febuari 2018 dari http://finance.detik.com.

Hery. (2015). Analisis Kinerja Manajemen. Jakarta : Grasindo

Marfuah, S.A dan Siti N. (2017). Pengaruh ukuran perusahaan, pertumbuhan aset, profitabilitas dan pertumbuhan penjualan terhadap struktur modal perusahaan cosmetics and household di Bursa Efek Indonesia. Jurnal Akuntansi dan Pajak, Vol.18, No.01, Juli 2017.

Munandar, A. (2014). Effect of Size, Profitability, and Growth Rate Towards Capital Structure. Jurnal Dinamika Manajemen Vol.2 No.3 Juli-September 2014.

Priyatno,D. (2013). Analisis Korelasi, Regresi dan Multivariate dengan SPSS. Yogyakarta: Gava Media.

Riyanto, B. (2001). Dasar-dasar Pembelanjaan Perusahaan. Yogyakarta: BPFE.

Batubara, R.A.P dan T. Z. (2017). Pengaruh Struktur Aktiva, Ukuran Perusahaan, dan Profitabilitas Terhadap Struktur Modal (Studi Pada Perusahaan Makanan dan Minuman yang Terdaftar di Bursa Efek Indonesia Tahun 2012-2015). Jurnal Administrasi Bisnis (JAB)|Vol. 50 No. 4 September 2017|.

Sholikhadi,L M \& Yahya (2016). Faktor-faktor yang Mempengaruhi Struktur Modal Perusahaan Kosmetik dan Keperluan Rumah Tangga di BEI. Jurnal Ilmu dan Riset Manajemen, Volume 5, Nomor 7. 
JAFTA — Vol. 1 Nomor 2, September (2019)

Sugiyono. (2012). Metode Penelitian Kuantitatif Kualitatif dan $R \& D$. Bandung: $\mathrm{CV}$ Alfabeta.

Wild,J, K.R.S dan R.F (2005). Financial Statement Analysis. Edisi 8. Jakarta: Salemba Empat.
Winarno, W.W. (2015). Analisis Ekonometrika dan Statistik dengan Eviews. Yogyakarta: UPP STIM YKPN.

Yulianti, S \& Prasetyo,H. (2005). Dasar- Dasar Manajemen Keuangan Internasional. Yogyakarta: Andi. 
JAFTA — Vol. 1 Nomor 2, September (2019)

\section{LAMPIRAN}

Berikut adalah data penelitian:

Tabel Data Penelitian

\begin{tabular}{|c|c|c|c|c|c|c|}
\hline No & $\begin{array}{c}\text { Kode } \\
\text { Perusahaan }\end{array}$ & Tahun & $\begin{array}{c}\text { Struktur Modal } \\
\text { DER } \\
\text { (TL/Equity) }\end{array}$ & $\begin{array}{c}\text { Firm Size } \\
\text { Ln (Penjualan) }\end{array}$ & $\begin{array}{c}\text { Profitabilitas } \\
\text { ROA }\end{array}$ & $\begin{array}{l}\text { Stuktur Aktiva } \\
\text { (FA/TA)x100\% }\end{array}$ \\
\hline \multirow{3}{*}{1} & \multirow{3}{*}{ AISA } & 2015 & 1.28 & 15.61 & 4.12 & 0.25 \\
\hline & & 2016 & 1.17 & 15.69 & 7.77 & 0.28 \\
\hline & & 2017 & 1.18 & 15.23 & 1.83 & 0.32 \\
\hline \multirow{3}{*}{2} & \multirow{3}{*}{ ALTO } & 2015 & 1.33 & 12.62 & $(2.06)$ & 0.49 \\
\hline & & 2016 & 1.42 & 12.60 & $(2.27)$ & 0.52 \\
\hline & & 2017 & 1.47 & 12.19 & (2.15) & 0.53 \\
\hline \multirow{3}{*}{3} & \multirow{3}{*}{ CEKA } & 2015 & 1.32 & 15.06 & 7.17 & 0.15 \\
\hline & & 2016 & 0.61 & 15.23 & 17.51 & 0.15 \\
\hline & & 2017 & 0.50 & 14.96 & 5.73 & 0.16 \\
\hline \multirow{3}{*}{4} & \multirow{3}{*}{ DLTA } & 2015 & 0.22 & 13.46 & 18.50 & 0.10 \\
\hline & & 2016 & 0.18 & 13.56 & 21.25 & 0.08 \\
\hline & & 2017 & 0.19 & 13.21 & 15.20 & 0.07 \\
\hline \multirow{3}{*}{5} & \multirow{3}{*}{ ICBP } & 2015 & 0.62 & 17.27 & 11.01 & 0.25 \\
\hline & & 2016 & 0.56 & 17.36 & 12.56 & 0.25 \\
\hline & & 2017 & 0.56 & 17.13 & 9.84 & 0.25 \\
\hline \multirow{3}{*}{6} & \multirow{3}{*}{ INDF } & 2015 & 1.13 & 17.98 & 4.04 & 0.27 \\
\hline & & 2016 & 0.87 & 18.02 & 6.41 & 0.31 \\
\hline & & 2017 & 0.92 & 17.79 & 4.89 & 0.34 \\
\hline \multirow{3}{*}{7} & \multirow{3}{*}{ MLBI } & 2015 & 1.74 & 14.81 & 23.65 & 0.60 \\
\hline & & 2016 & 1.77 & 15.00 & 43.17 & 0.56 \\
\hline & & 2017 & 1.59 & 14.66 & 37.10 & 0.53 \\
\hline \multirow{3}{*}{8} & \multirow{3}{*}{ MYOR } & 2015 & 1.18 & 16.51 & 11.02 & 0.33 \\
\hline & & 2016 & 1.06 & 16.73 & 10.75 & 0.30 \\
\hline & & 2017 & 1.06 & 16.48 & 6.86 & 0.28 \\
\hline \multirow{3}{*}{9} & \multirow{3}{*}{ ROTI } & 2015 & 1.28 & 14.59 & 10.00 & 0.67 \\
\hline & & 2016 & 1.02 & 14.74 & 9.58 & 0.63 \\
\hline & & 2017 & 1.03 & 14.42 & 3.08 & 0.64 \\
\hline \multirow{3}{*}{10} & \multirow{3}{*}{ SKBM } & 2015 & 1.22 & 14.12 & 5.25 & 0.51 \\
\hline & & 2016 & 1.72 & 14.22 & 2.25 & 0.44 \\
\hline & & 2017 & 0.52 & 14.08 & 0.24 & 0.31 \\
\hline \multirow{3}{*}{11} & \multirow{3}{*}{ SKLT } & 2015 & 1.48 & 13.52 & 5.32 & 0.39 \\
\hline & & 2016 & 0.92 & 13.63 & 3.63 & 0.53 \\
\hline & & 2017 & 0.96 & 13.43 & 2.70 & 0.50 \\
\hline \multirow{3}{*}{12} & \multirow{3}{*}{ STTP } & 2015 & 0.90 & 14.75 & 9.67 & 0.52 \\
\hline & & 2016 & 1.00 & 14.78 & 7.45 & 0.49 \\
\hline & & 2017 & 0.73 & 14.56 & 7.18 & 0.50 \\
\hline \multirow{3}{*}{13} & \multirow{3}{*}{ ULTJ } & 2015 & 0.27 & 15.30 & 14.78 & 0.33 \\
\hline & & 2016 & 0.21 & 15.36 & 16.74 & 0.25 \\
\hline & & 2017 & 0.18 & 15.09 & 13.28 & 0.26 \\
\hline
\end{tabular}

Tabel 3.3 Sampel Penelitian 
JAFTA — Vol. 1 Nomor 2, September (2019)

\begin{tabular}{llc} 
No. & Nama Perusahaan & Kode Perusahaan \\
\hline 1 & Tiga Pilar Sejahtera Food Tbk, PT & AISA \\
2 & Tri Banyan Tirta Tbk, PT & ALTO \\
3 & Wilmar Cahaya Indonesia Tbk, PT & CEKA \\
4 & Delta Djakarta Tbk, PT & DLTA \\
5 & Indofood CBP Sukses Makmur Tbk, PT & ICBP \\
6 & Indofood Sukses Makmur Tbk, PT & INDF \\
7 & Multi Bintang Indonesia Tbk, PT & MLBI \\
8 & Mayora Indah Tbk, PT & MYOR \\
9 & Nippon Indosari Corporindo Tbk, PT & ROTI \\
10 & Sekar Laut Tbk, PT & SKLT \\
11 & Siantar Top Tbk, PT & STTP \\
12 & Ultrajaya Milk Industry and Trading Company Tbk, PT & ULTJ \\
13 & Sekar Bumi Tbk, PT & SKBM \\
\hline
\end{tabular}

Sumber: Data diolah peneliti 
JAFTA — Vol. 1 Nomor 2, September (2019) 